\title{
A calcium-activated, calcium-permeable ion channel in human retinal glial cells: modulation by basic fibroblast growth factor
}

\author{
Donald G. Puro \\ Departments of Ophthalmology and Physiology, University of Michigan School of Medicine, 1000 Wall Street, Ann Arbor, MI 48105 (U.S.A.)
}

(Accepted 22 January 1991)

Key words: Ion channel; Retinal glia; Muller cell; Cation; Calcium; Patch clamp; Cell culture; Basic fibroblast growth factor

\begin{abstract}
A calcium-permeable, voltage-insensitive non-specific cation channel that is activated by cytoplasmic calcium was found in approximately $50 \%$ of the cell-attached patches in cultured human retinal glial cells sampled by the patch clamp technique. Spontaneous openings of this channel were infrequent, but increased markedly when glial cells were exposed to basic fibroblast growth factor. Although the role of these cation channels is uncertain, they provide a mechanism to perpetuate a transient rise in cytosolic calcium induced by the release of calcium from intracellular stores.
\end{abstract}

Calcium plays a role in many important cellular activities, including responses to various growth factors. Cytosolic calcium is regulated, in part, by the release of calcium from intracellular stores and an influx of calcium across the cell membrane. Both routes for increasing free calcium in the cell appear to be enhanced after exposure to certain growth factors ${ }^{14}$. However, knowledge concerning transcellular pathways for a growth factorinduced calcium influx is limited, although recent studies of cells from outside the nervous system show that a calcium influx may occur via ion channels that are voltage-insensitive $e^{9,11,19}$.

In the nervous system, glial cells are targets for many growth factors. In this study, I asked whether glial cells from the retina have voltage-insensitive, calcium-permeable channels that are activated with exposure of the cell to an endogenous retinal growth factor, basic fibroblast growth factor (bFGF). I found that cultured glial cells from the adult human retina have voltage-insensitive, non-selective cation channels that are permeable to calcium. Use of excised patches demonstrated a sensitivity of this type of cation channel to calcium at the cytoplasmic side. In cell-attached patches, the activity of these non-specific channels increased markedly when the glial cells were exposed to bFGF.

Cultures of human retinal glial cells were prepared as described previously ${ }^{7,16}$. In brief, postmortem eyes from donors aged 17 to 93 years were supplied within $24 \mathrm{~h}$ of death by the Florida Lions and Michigan Eye Banks. Retinas were removed, exposed to a calcium- and magnesium-free phosphate buffer supplemented with $0.1 \%$ trypsin ( $\times 3$ crystallized, Worthington), $0.2 \%$ hyaluronidase (Sigma) and $4 \%$ chicken serum (GIBCO) for 45 min at $37{ }^{\circ} \mathrm{C}$ and then dissociated mechanically in $80 \%$ medium A (1:1 ratio of Dulbecco's modified Eagle's medium and Ham's F-12 medium) and 20\% fetal bovine serum. Dissociated cells were added to plastic Petri dishes, kept in a humidified environment of $97 \%$ air and $3 \% \mathrm{CO}_{2}$ at $37{ }^{\circ} \mathrm{C}$, fed twice a week with $80 \%$ medium $\mathrm{A}$ and $20 \%$ fetal bovine serum, and split when they reached confluency. Cells that had been in culture for 1 to 3 passages were used. As reported elsewhere ${ }^{7,16}$, virtually all of the cells stained positively for glial fibrillary acidic protein. Ultrastructural studies ${ }^{7,16}$ of these cultured cells have demonstrated the presence of $10 \mathrm{~nm}$ cytoplasmic filaments, which are characteristic of glial cells. In addition, as published previously ${ }^{16}$, nearly all the cells in these cultures stained positively by immunocytochemistry with a monoclonal antibody for Muller glial cells.

Ion currents were recorded with the patch clamp technique using the cell-attached and excised-patched configurations ${ }^{4}$. One day prior to recording, cultures were washed twice and kept in medium B (medium A supplemented with $50 \mu \mathrm{g} / \mathrm{ml}$ transferrin and $30 \mathrm{nM}$ sodium selenite). Approximately $1-2 \mathrm{~h}$ prior to recording, medium $B$ was replaced with a bathing solution. Unless stated otherwise, the bathing solution for cellattached patch recordings consisted of $140 \mathrm{mM} \mathrm{K}$ aspartate, $4 \mathrm{mM} \mathrm{CaCl}_{2}, 1 \mathrm{mM} \mathrm{MgCl}, 10 \mathrm{mM}$ glucose and $10 \mathrm{mM}$ K-HEPES (pH 7.3). This bathing solution 
effectively zeroed the resting membrane potential as evidenced by unitary currents remaining unchanged after patch excision. A bathing solution containing $10^{-5} \mathrm{M}$ $\mathrm{Ca}^{2+}$ could be miniperfused by applying $0.5 \mathrm{psi}$ of pressure from a pressure ejection system (Medical Systems) to the back end of a pipet with a tip size of approximately $5 \mu \mathrm{m}$ that was positioned about $100 \mu \mathrm{m}$ from the excised patch being studied. In experiments examining changes in channel activity after exposure of glial cells to recombinant bovine bFGF (Amgen), $1.5 \mu \mathrm{l}$ of $200 \mathrm{ng} / \mathrm{ml} \mathrm{bFGF}$ was added to the bath (total volume $=1.5 \mathrm{ml}$ ). Recording pipets were filled with $100 \mathrm{mM}$ $\mathrm{BaCl}_{2}, 10 \mu \mathrm{M}$ tetrodotoxin, $5 \mathrm{mM}$ tetraethylammonium and $10 \mathrm{mM} \mathrm{Ba-HEPES} \mathrm{(pH} \mathrm{7.3),} \mathrm{unless} \mathrm{otherwise} \mathrm{noted.}$ Currents were recorded with a Dagan 3900 patch clamp amplifier or a Dagan 8900 amplifier having a $10 \mathrm{G} \Omega$ headstage. Fire-polished pipets of borosilicate glass (1.5 $\mathrm{mm}$ diameter, fiber-filled, WPI) coated with Sylgard no. 184 (Dow Corning) had resistances of 6-9 M $\Omega$. Pipet potentials were adjusted to zero current flow before establishment of seals. Membrane-pipet seals were $>10$ $\mathrm{G} \Omega$. Current signals were filtered at $1 \mathrm{kHz}$. Ion currents could be digitalized (Neuro-corder, Neuro Data Instr) and stored on videotape for later analysis. For measurements of the percent of time that an ion channel was opened, an increase in current greater than $50 \%$ of the unitary channel current was interpreted as a channel opening. Once open, a decrease in the current to $50 \%$ of the single channel level was defined as a channel closing. Computer software (pClamp, version 5.5, Axon Instr) aided in the assessment of percent open time, which was determined for 1-min periods. Experiments were carried out at room temperature, approximately $22{ }^{\circ} \mathrm{C}$.

Cell-attached patch recordings from human retinal glial cells were performed with a pipet solution containing tetrodotoxin to block sodium channels, tetraethylammonium to block potassium channels and barium to minimize potassium channel activity and to help detect ion channels permeable to divalent cations. In approximately $50 \%$ of the cell-attached patches sampled, there was an ion channel with a mean unitary conductance of $17 \mathrm{pS}$ (S.D. $=3.0, n=24$, calculated between $-100 \mathrm{mV}$ and $+100 \mathrm{mV}$ ) and with a reversal potential near $0 \mathrm{mV}$. There was some outward rectification of the currents (Fig. 1A). There was no marked voltage-sensitivity of this channel. Although a subtle effect of voltage would have been difficult to detect due to spontaneous variability in channel activity, these $17 \mathrm{pS}$ channels clearly differ from the voltage-gated $\sim 10 \mathrm{pS}$ and $-25 \mathrm{pS}$ barium-permeable channels also found in these glial cells (unpublished observations).

The ionic selectivity of this ion channel was investigated by comparing current-voltage relationships for single channels in cell-attached patches with differing ion species in the pipet solution. With $150 \mathrm{mM}$ K-aspartate or $\mathrm{KCl}$ in the pipet, the reversal potential was near $0 \mathrm{mV}$ (Fig. 1B), indicating no significant permeability to chloride. Since chloride permeability is minimal, the inward currents observed with either potassium or barium in the pipet were due to an influx of these cations. Inward currents also occurred at negative membrane potentials when the recording pipet contained calcium (Fig 1C) or
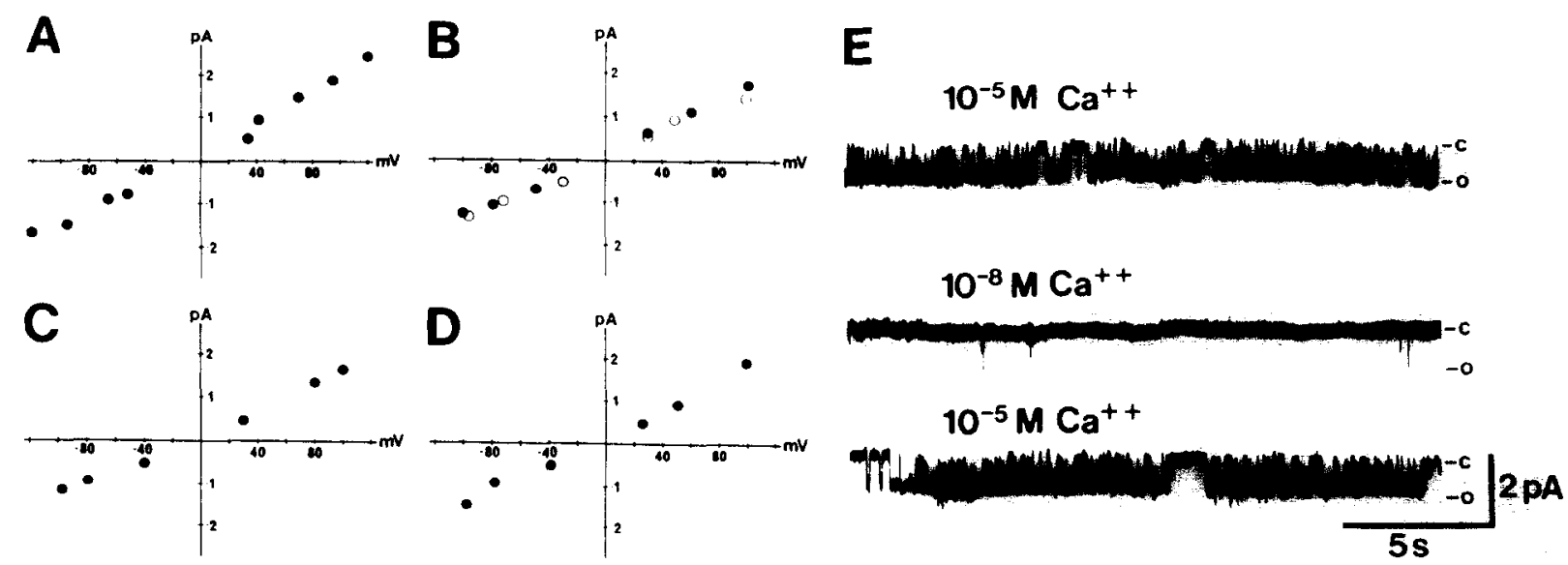

Fig. 1. A-D: current-voltage relationships for ion channels in cell-attached patches of human retinal glial cells in culture. In $A$, the pipet solution included isotonic $\mathrm{BaCl}_{2}$. In $\mathrm{B}$, the closed circles indicate results with $150 \mathrm{mM} \mathrm{K}$-aspartate in the pipet solution. Open circles show findings with $150 \mathrm{mM} \mathrm{KCl}$. In $\mathrm{C}$, the pipet solution included isotonic $\mathrm{CaCl}_{2}$. In $\mathrm{D}, 150 \mathrm{mM} \mathrm{NaCl}$ was in the pipet solution. All pipet solutions contained $5 \mu \mathrm{M}$ tetrodotoxin, $5 \mathrm{mM}$ tetraethylammonium and $10 \mathrm{mM}$ HEPES. The conductances between $-100 \mathrm{mV}$ and $+100 \mathrm{mV}$ were 17 $\mathrm{pS}, 14 \mathrm{pS}, 14 \mathrm{pS}$ and $17 \mathrm{pS}$ for barium, potassium, calcium and sodium, respectively. In $\mathrm{E}$, the effect of varying the calcium concentration at the cytoplasmic surface of an excised inside-out patch containing a $17 \mathrm{pS}$ cation channel is shown. Immediately prior to patch excision, the bathing solution was changed to one containing $10^{-8} \mathrm{M} \mathrm{Ca}^{2+}(0.32 \mathrm{mM} \mathrm{CaCl}$ plus $1 \mathrm{mM}$ EGTA $)$. The top and bottom panels show ion channel activity when a bathing solution with $10^{-5} \mathrm{M} \mathrm{Ca}^{2+}$ was miniperfused in the area of the excised patch. The pipet solution contained isotonic $\mathrm{BaCl}_{2}$. The holding potential was $-60 \mathrm{mV}$. The letters $\mathrm{c}$ and o indicate the current level for closed and open channels, respectively. 
sodium (Fig. 1D). Reversal potentials near $0 \mathrm{mM}$ with isotonic potassium, sodium, calcium or barium in the patch pipets (Fig. 1A-D) indicate a poor discrimination between monovalent and divalent cations.

Excised, inside-out patches were used to study the effect of calcium at the cytoplasmic surface on the activity of this cation channel. Excision did not significantly affect the mean conductance $(15 \mathrm{pS}$, S.D. $=2, n=9)$. With local perfusion of the cytoplasmic side of the patch with a bathing solution containing $10^{-5} \mathrm{M} \mathrm{Ca}^{2+}$, there was a significant amount of channel activity (Fig. 1E, top panel). Exposure of the cytoplasmic surface to a solution with $10^{-8} \mathrm{M} \mathrm{Ca}^{2+}$ reversibly reduced the activity of this ion channel (Fig. 1E, middle panel). A calcium-sensitivity was demonstrated in two other excised patches containing channels with the characteristics of the $17 \mathrm{pS}$ non-specific cation channel. In each excised patch studied, the sensitivity of these cation channels to calcium decreased with time. After $5 \mathrm{~min}$ in an excised patch, the $17 \mathrm{pS}$ cation channels required as much as $1 \mathrm{mM} \mathrm{Ca}^{2+}$ at the cytoplasmic surface in order for frequent channel openings to occur. Neither voltage-sensitivity nor stretchactivation of these channels were detected in excised patches. As is evident from Fig. 1E, the duration of channel openings varied from a few msec to hundreds of msec.

In cell-attached patches, the spontaneous activity of non-specific cation channels typically was low although channel openings could be relatively frequent during the initial minutes after formation of a pipet-cell seal. To help quantitate the spontaneous activity of these ion channels, their percent open times were calculated at 1-min intervals over a period of $\geqslant 5 \mathrm{~min}$ beginning 5-10 $\mathrm{min}$ after forming a cell-attached patch. Calcium-permeable, non-specific cation channels were identified by their having $\mathrm{Ca}^{2+}$ currents with conductances of $15-20 \mathrm{pS}$, lacking detected voltage-sensitivity and having reversal potentials near $0 \mathrm{mV}$. In the bathing solution containing $\mathrm{K}$-aspartate, the mean percent open time was $0.4 \%$ (S.D. $=0.5 \%, n=4)$. Recording in a non-depolarizing bathing solution (137 mM NaCl, $5.4 \mathrm{mM} \mathrm{KCl}_{2}, 6 \mathrm{mM} \mathrm{CaCl}_{2}, 10$ $\mathrm{mM}$ glucose and $10 \mathrm{mM}$ Na-HEPES), the mean percent open time in cell-attached patches was $0.2 \%$, (S.D. = $0.2, n=4)$. The difference in the mean percent open time under depolarizing and non-depolarizing conditions was not significant $(P>0.5$, Student's $t$-test). For each channel analyzed, the standard deviation of the percent open time was relatively large. A significant variability in spontaneous activity is also reported for other types of calcium-activated non-specific cation channels ${ }^{15}$. Reliable kinetic measurements of the activity of these ion channels await determination of the basis for their non-stationary behavior.

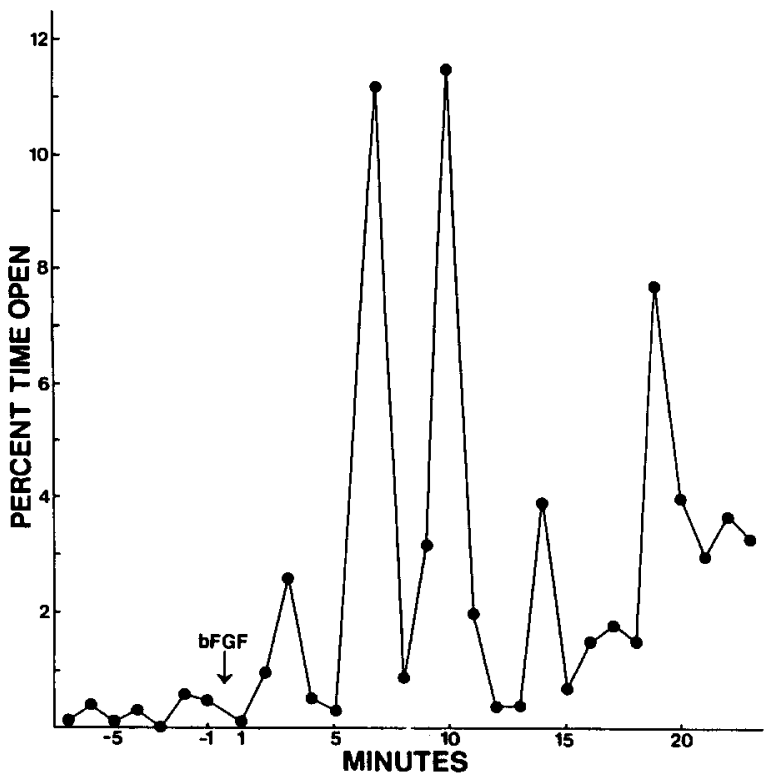

Fig. 2. Effect of bFGF on the percent open time of a voltageinsensitive, calcium-permeable ion channel in a cell-attached patch on a retinal glial cell. The percent of time that the channel was open was determined at 1-min intervals. At the time indicated by the arrow, bFGF (final concentration $200 \mathrm{pg} / \mathrm{ml}$ ) was added to the bathing solution. The bathing solution consisted of $137 \mathrm{mM} \mathrm{NaCl}$, $5.4 \mathrm{mM} \mathrm{KCl}, 6 \mathrm{mM} \mathrm{CaCl}_{2}, 10 \mathrm{mM}$ glucose and $10 \mathrm{mM} \mathrm{Na}$-HEPES $\mathrm{pH}$ 7.35. The pipet contained an isotonic barium solution. $A$ potential of $+93 \mathrm{mV}$ was applied to the pipet to enhance the size and, thus, the detection of single channel currents. Calculations of percent open time began $15 \mathrm{~min}$ after establishment of the pipet-cell seal.

The results presented show that human retinal glial cells in culture have calcium-activated, voltage-insensitive, calcium-permeable, non-specific cation channels. The spontaneous activity of these channels is generally low with the channels being closed greater than $99 \%$ of the time under the recording conditions used in this study. Under what conditions are these channels opened more of the time? The possibility that exposure to basic fibroblast growth factor (bFGF) may be associated with an increase in the activity of these cation channels was examined. This growth factor was chosen for study for several reasons. It is endogenous to the retina ${ }^{3}$, retinal glia have bFGF-receptors ${ }^{8}$, and measurements of intracellular calcium levels in some cells indicate that exposure to bFGF is associated with an influx of calcium from the extracellular space ${ }^{6,13}$ via undefined pathways. Perhaps in retinal glial cells the non-specific cation channel provides a pathway for calcium to enter the cell after bFGF-exposure. To look for an effect of bFGF, ion channels with characteristics of the cation channel presented in this report were monitored continuously in cell-attached patches before and after exposure of the glial cell to bFGF. Fig. 2 shows the percent open time for a non-specific cation channel before and after addition of bFGF to the bathing solution. During a 7 -min period 
prior to bFGF-exposure, this ion channel was opened a mean of $0.3 \%$ (S.D. $=0.2$ ) of the time. For the period of 1 to 23 min after the addition of bFGF, the mean percent open time increased more than 10 -fold to $3.1 \%$ (S.D. $=3.2)$. This increase was statistically significant $(P$ $=0.03$, Student's $t$-test). Three other cell-attached patches with this type of cation channel were also examined for possible bFGF-effects. The mean percent open time assayed during the first 10-30 min after bFGF addition was $795 \%$ (S.D. $=504$ ) higher than during the control periods. In 3 control experiments, cell-attached patches with the non-specific cation channel were monitored for at least $20 \mathrm{~min}$ without the addition of bFGF. There were no significant $(P>0.05)$ increases in the mean percent open times. This contrasts with the increases observed after the addition of bFGF.

As is evident in Fig. 2, large oscillations in the percent open time occurred after bFGF-exposure. Kinetic analyses of channel activity to help determine possible mechanisms for the bFGF-associated change in channel activity await determination of the basis for the markedly non-stationary behavior of these ion channels. The fluctuations in channel activity may reflect oscillatory changes in free calcium levels as detected in a variety of cell types ${ }^{17}$, including glia $^{2}$. Future experiments monitoring calcium levels in retinal glial cells are needed to assess this possibility.

The results presented in this report show that human retinal glial cells in culture have a calcium-activated, non-specific cation channel that is permeable to monovalent and divalent ions. This cation channel is similar to an 18 to $25 \mathrm{pS}$ cation channel found in human neutrophils ${ }^{19}$. Similarities include permeability for divalent as well as monovalent cations, calcium-activation, minimal voltage-sensitivity, modest outward rectification and low spontaneous activity. A significant permeability to calcium distinguishes the non-specific cation channels

1 Bevan S., Gray, P.T.A. and Ritchie, J.M., A calcium-activated cation-selective channel in rat cultured Schwann cells, Proc. $R$. Soc. Lond. Ser. B, 222 (1984) 349-355.

2 Cornell-Bell, A.H., Finkbeiner, S.M., Cooper, M.S. and Smith, S.J., Glutamate induces calcium waves in cultured astrocytes: long-range glial signaling, Science, 247 (1990) 470-473.

3 Gospodarowicz, D., Neufeld, G. and Schwigerer, L., Molecular and biological characterization of fibroblast growth factor, an angiogenic factor which also controls proliferation and differentiation of mesoderm- and neuroectoderm-derived cells, Cell Differentiation, 19 (1986) 1-17.

4 Hamill, D.P., Marty, A., Nehr, E., Sakmann, B. an Sigworth, F.J., Improved patch clamp techniques for high-resolution current recordings from cell and cell-free membrane patches, Pflügers Arch., 391 (1981) 85-100.

5 Machemer, R., Pathogenesis and classification of massive periretinal proliferation, $B r . J$. Ophthalmol., 62 (1978) 737-747.

6 Magnaldo, I., L'Allemain, G., Chambard, J.C., Moenner, M., Barretault, D. and Pouyssegur, J., The mitogenic signalling of retinal glia and neutrophils from the exclusively monovalent permeable cation channels found in a variety of other cell types ${ }^{15}$, including glial cells of the peripheral nervous system ${ }^{1}$.

A further similarity of the non-specific cation channels of retinal glia and neutrophils is the regulation of channel activity by extracellular peptides, bFGF in the case of retinal glia and the chemotactic molecule, $N$-formylmethionyl-leucyl-phenylalanine (fMLP), for neutrophils ${ }^{19}$. The effects of bFGF and AMLP on channel activity are likely to involve a second messenger system, with intracellular calcium being one possible candidate.

Although the effect of bFGF on intracellular levels of calcium in retinal glial cells is unknown, in other cell types exposure to bFGF is associated with an initial release of calcium from intracellular stores followed by a longer-lasting calcium influx across the cell membrane ${ }^{13}$. Pathways for calcium influx after bFGF-exposure are uncertain. The type of non-specific cation channel found in this study of retinal glial cells provides a possible mechanism for calcium to enter the cell after an initial bFGF-mediated release of calcium from intracellular stores.

Since calcium is involved in many important intracellular events, a bFGF-enhanced influx could significantly affect glial function. For example, increasing cytosolic calcium could activate calcium-sensitive potassium channels and, thereby, influence the regulation by glia of extracellular potassium homeostasis. Also, calcium may play a role in glial cell activities, such as chemotaxis and proliferation, that occur in the retina under a variety of pathophysiological conditions $s^{5,12}$ in which bFGF is thought to play a role ${ }^{3,18}$.

This work was supported by Grants EYO6931 and EYO7003 from the National Eye Institute, National Institutes of Health, Bethesda, MD.

pathway of fibroblast growth factor is not mediated through polyphosphoinositide hydrolysis and protein kinase $\mathrm{C}$ activation in hamster fibroblasts, J. Biol. Chem., 261 (1986) 16916-16922.

7 Mano, T. and Puro, D.G., Phagocytosis by human retinal glial cells in culture, Invest. Opthalmol. Vis. Sci., 31 (1990) 10471055.

8 Mascarelli, J., Tassin, J. and Courtois, Y., Fibroblast growth factor phosphorylation and receptors in rod outer segments. Interaction with glial cells: intracrine and paracrine role on retina, Invest. Opthalmol. Vis. Sci., 31 (Suppl.) (1990) 227.

9 Meldolesi, J. and Pozzan, T., Pathways of $\mathrm{Ca}^{2+}$ influx at the plasma membrane: voltage-receptor and second messengeroperated channel, Exp. Cell Res., 171 (1987) 271-283.

10 Merritt, J. and Rink, T., Regulation of cytosolic free calcium in fura-2 loaded rat parotid acinar cells, J. Biol. Chem., 262 (1987) 17362-17369.

11 Neher, E., Receptor-operated Ca channels, Nature, 326 (1987) 242-243.

12 Nork, T.M., Wallow, I.H.L., Sramek, S.J. and Anderson, G., 
Muller's cell involvement in proliferative diabetic retinopathy, Arch. Opthalmol., 105 (1987) 1424-1429.

13 Pandrella, A., Magni, M. and Meldolesi, J., Plasma membrane hyperpolarization and $\left[\mathrm{Ca}^{2+}\right]$; increase induced by fibroblast growth factor in NIH-3T3 fibroblasts, Biochem. Biophys. Res. Commun., 163 (1989) 1325-1331.

14 Penner, R., Matthews, G. and Neher, E., Regulation of calcium influx by second messengers in rat mast cells, Nature, 334 (1988) 499-504.

15 Partridge, L.D. and Swandulla, D., Calcium-activated nonspecific cation channels, Trends Neurosci., 11 (1988) 69-72.

16 Puro, D.G., Mano, T., Chan C.-C., Fukuda, M. and Shimada,
H., Thrombin stimulates the proliferation of human retinal glial cells, Graefe's Arch. Clin. Exp. Ophthalmol., 228 (1990) 169-173.

17 Rink, T.J. and Jacob, R., Calcium oscillations in non-excitable cells, Trends Neurosci., 12 (1989) 43-46.

18 Sivalingam, A., Kenny, J., Brown, G.C., Benson, W.E. and Conoso, L., Basic fibroblast growth factor levels in the vitreous of patients with proliferative diabetic retinopathy, Arch. Ophthalmol., 108 (1990) 869-872.

19 von Tscharner, V., Prod'hom, B., Baggiolini, M. and Reuter, $H$., Ion channels in human neurtrophils activated by a rise in free cytosolic calcium concentration, Nature, 324 (1986) 369-372. 